\title{
Towards a Taxonomy of E-commerce: Characterizing Content Creator-Based Business Models
}

\author{
Martin D. Mileros, Nicolette Lakemond and Robert Forchheimer
}

\author{
" True value is content in context." \\ L. Gordon Crovitz \\ Former president, \\ Dow Jones Electronic Publishing
}

\begin{abstract}
Currently, new business models can be observed in content creator-based e-commerce. The research on e-commerce has grown rapidly and new concepts have emerged such as social commerce, platforms, and user-generated content. However, no overarching perspective has yet been formulated for distinguishing new content creator-based business models within ecommerce. The aim of this paper is therefore to characterize content creator-based business models by formulating a taxonomy of e-commerce based on a structured literature review of the concepts mentioned above. The results of our study point toward eight types of content creatorbased business models. Our paper outlines theoretical and practical implications for the emerging phenomenon of content creator-based business, which we refer to as intellectual commerce. In addition, we describe 19 concepts related to Web 1.0, Web 2.0, and e-commerce.
\end{abstract}

\section{Introduction}

During the past 15 years, consumers have become important actors in creating content in digital media and on digital platforms. Some of them have succeeded in monetizing their efforts. This group of content creators tend to be business-oriented, and are represented, for example, by bloggers (Van Esch et al., 2018), YouTubers, and gamers (Postigo, 2016), who can more or less make a living from their activities on the Internet. It has been argued for instance that content creators in virtual worlds can earn hundreds of thousands of dollars (Scarle et al., 2012). The businesses of these content creators are partially based on a combination of e-commerce (Zwass, 1996) and user-generated content (UGC), which is defined as publicly accessible creative works made by non-professionals (Banks \& Humphreys, 2008; Figallo \& Rhine, 2001). The phenomenon of business-oriented content creators is growing and a new type of business model seems to be emerging. Although increasing awareness is growing that content creator-based business exists, the importance of user-generated content and the consumer perspective on both consumer-to-business (C2B) and consumer-toconsumer $(\mathrm{C} 2 \mathrm{C})$ e-commerce have received relatively little attention in the literature (Vanmeter et al., 2015; Wang et al., 2002; Yrjölä et al., 2017).
As current research is still scarce and disparate, more insight is needed into how to connect this new phenomenon to the current knowledge of business models (Foss \& Saebi, 2016), in order to understand content creator-based business and outline their characteristics. Several literature streams have been identified as relevant that may form a foundation for understanding the new content creator-based businesses that are being established. These include ecommerce (Zwass, 1996), social commerce (Stephen \& Toubia, 2009), platforms (Dufva et al., 2017; Hagiu \& Wright, 2014; Korhonen et al., 2017), and user-generated content (Van Dijck, 2009). Based on an overview of the current literature, we explore how insights from businesses and content creators within e-commerce and social commerce may be relevant for understanding the emergence of business-oriented content creators and their various types of business models.

The literature on business models and e-commerce (Amit \& Zott, 2001) is rapidly growing. Although there is an abundance of definitions and results available, there is still a lack of a coherent terminology. For example, scholars describe the new business models in different ways, using different concepts (Cucculelli \& Bettinelli, 2015; Foss \& Saebi, 2016; Jensen, 2014; Kotarba, 2018; Weill et al., 2011; Zott et al., 2011). Examples of the 


\section{Towards a Taxonomy of E-commerce: Characterizing Content Creator-Based Business Models Martin D. Mileros, Nicolette Lakemond and Robert Forchheimer}

different e-commerce concepts that are available in the field are, for instance, pure e-commerce, partial ecommerce, long tail, short tail, consumer-to-business, consumer-to-consumer, two-sided markets, multisided platforms, copyright and blockchains (descriptions of the concepts are found in the Appendix). Some research has focused on business models and e-commerce (Timmers, 1998), some on business models and usergenerated content (Harrison \& Barthel, 2009), and others on business models and consumer-to-consumer relations (Wang \& Zhang, 2012).

An integrated and holistic understanding is nevertheless lacking, while it seems that studies concerning ecommerce and related concepts have focused on creating contributions often with quite narrow views, rather than on producing an overarching perspective that includes central concepts. A similar observation has been made related to business model research (Zott et al., 2011). By using e-commerce as a common denominator, the aim of this paper is to increase understanding of the emerging phenomenon of content creator-based business models. Our particular interest concerns the following questions: (1) How can content creator-based business models be characterized?, and (2) What are the specific characteristics of how value is created, captured and protected by content creators?

\section{Studies of Business Models}

Despite being introduced by scholars during the 1960s, '70s and '80s, the business model (BM) concept did not become popular in the web community until the late 1990s, when it was boosted by media as a buzzword in the emerging era of e-commerce (Chesbrough \& Rosenbloom, 2002; Frankenberger et al., 2013). There is still no generally accepted definition of a business model. Instead there are many different interpretations and characterizations of what a business model really is. Timmers (1998) defined business model as an architecture for product, service, and information flow, including a description of the various business actors and their roles, a description of potential benefits for the actors, and a description of sources and revenues. He also identified three types of structures within ecommerce: the e-shop, e-mall and e-auction. Amit and Zott (2001) explored the theoretical foundations of ebusiness using several theoretical perspectives, including transaction cost economics, resource-based views, Schumpeterian innovations (for example, creative destruction and value creation), and strategic networks. They concluded that all of these perspectives provide insights into the drivers of value creation in e-business and contribute to understanding the business models underlying e-commerce. Based on their work, they suggest that the main sources of value creation in ebusinesses are connected to efficiency, complementarity, novelty, and lock-in (for instance, key features of a service which keeps the user attracted to the service) (Zott \& Amit, 2010). Several definitions of business models have recently been introduced. For instance, Teece (2010) described a business model as the design or architecture of value creation, value delivery, and value capture mechanisms employed by a particular business. Chesbrough (2007) pointed out that the business model is more important than the technology itself, and that every company has a business model whether they articulate it or not. Other scholars, such as Baden-Fuller and Morgan (2010), have argued that the business model and business model innovation are key components to competitive advantage. Chesbrough (2007) also suggested a business model framework for assessing the potential for business model innovation, in other words changing the existing business model or creating a new business model. Business model innovation has been defined by Björkdahl and Holmén (2013) as the implementation of a new business model to the firm. Frankenberger et al. (2013) instead stressed that business model innovation represents a novel way that businesses create and capture value.

During the same period, along with increasing awareness about the importance of e-commerce, Anderson (2007) articulated the differences between traditional commerce and e-commerce. He specifically stressed that e-commerce allows for a so-called long tail. Compared to the traditional short-tail demand curve where the market consists of a few high-volume producers, many niche products and low volumes in the long tail may actually result in higher value (Anderson, 2008; Swan, 2017).

During the last decade, several structures and typologies have emerged, such as the Business Model Canvas (Osterwalder \& Pigneur, 2010), the St. Gallen Business Model Navigator (Gassmann et al., 2013), and the five-V framework (Taran et al., 2015). As the business model concept developed rapidly, it created complexity and diversity within the research field. Zott et al. (2011) pointed out that current literature largely has been conducted in silos, according to the interest of each respective researcher. Other scholars, such as Weill et al. (2011) and Cucculelli and Bettinelli (2015), agree that there is a lack of consensus among scholars of what a business model really is. Some of them have questioned whether there is a need for a universally accepted view (Jensen, 2014). This culminated in the paper "Fifteen Years of Research on Business Model Innovation: How 


\section{Towards a Taxonomy of E-commerce: Characterizing Content Creator-Based Business Models Martin D. Mileros, Nicolette Lakemond and Robert Forchheimer}

Far Have We Come, and Where Should We Go?" (Foss \& Saebi, 2016), where they concluded that business models are important, but that research lacks underpinning and that the empirical inquiry is not cumulative, and therefore lacks clarity regarding gaps, contingencies and outcomes.

\section{Method}

In order to characterize content creator-based business models, we collected secondary data on current ecommerce-related literature, focusing on the concepts and terminology that are central in the literature. The study was carried out between January and September 2019 , and was mainly based on a systematic literature review of peer-reviewed articles using the database Scopus. We started our initial search with search terms such as e-commerce, social commerce, platforms, and user-generated content. These search terms emerged from an initial understanding and readings of the few contributions made on e-commerce and user-generated content. The main search terms (main concepts) are presented in Table 1. We limited our search to journals in the areas of social sciences, business management and accounting and economics, econometrics and finance. In addition, to limiting the search scope, we decided to leave out all articles that were specifically focused on business-to-business (B2B) relationships. We also did not consider any business-to-government (B2G) or consumer-to-government relationships (C2G). The term platform resulted in too many irrelevant results $(13,903)$ for which reason we decided to start our search using multisided platforms which gave 27 results.

Our selection of relevant articles for each term was then carried out in three steps. First, we viewed all, or at least the top hundred most cited articles, and downloaded the full article of the most relevant, according to their titles and abstracts. Second, we carried out the same procedure by viewing the oldest articles with the intent to find origins and definitions, and also to provide material for an overarching view (for example, how and when terms were introduced). Third, we viewed and downloaded the newest and most relevant articles in order to be able to include current emerging terms and results. We also applied the snowball method, in other words, some of the articles generated new references and new terms (additional concepts), which we decided to include in our work, see Table 1.

We also discovered other related keywords, and in order to determine their relevance and importance, analyzed them by counting the total number of articles as well as plotting a trend curve for each term between 1991 and 2019 (see Table 2). The search was carried out on Scopus with the same limitations as above, except that we also included the occurrence of conference papers. Our main concepts are important due to a large number of articles,

\begin{tabular}{lr} 
Main concepts & Results \\
\hline \{e-commerce\} OR \{electronic commerce\} & 10,162 \\
\{Multisided platforms\} & 23 \\
\{Social commerce\} & 262 \\
\{User-generated content\} OR \{User generated content\} & 1,238
\end{tabular}

\begin{tabular}{lr} 
Additional concepts & Results \\
\hline$\{$ E-business\} & 1,613 \\
\{Consumer-to-consumer\} OR \{C2C\} & 253 \\
\{Consumer-to-business\} OR \{C2B\} & 17 \\
\{Content platforms\} & 21 \\
\{Long-tail\} OR \{Long tail\} & 291 \\
\{Pure e-commerce\} OR \{Full e-commerce\} & 2 \\
\{Online-to-offline e-commerce\} OR \{O2O commerce\} & 2 \\
$\{$ Technological platforms\} & 15 \\
$\{$ User-created content\} OR \{User created content\} & 94 \\
$\{$ Virtual commerce\} & 34 \\
& 4
\end{tabular}

Table 1. Search terms on Scopus 


\section{Towards a Taxonomy of E-commerce: Characterizing Content Creator-Based Business Models Martin D. Mileros, Nicolette Lakemond and Robert Forchheimer}

such as 26,397 for e-commerce, and also because of an ascending trend for social commerce, multisided platforms, and user-generated content. It can also be seen that some of the concepts started being used much earlier than when they gained broader attention, such as by word-of-mouth or long tail. (We also found several other types of commerce, such as Collaborative, Facebook, Knowledge, Location, Mobile, Online-tooffline, Tablet, and Virtual commerce. We will not explain and include these concepts in our work, but decided to include them in Table 2 as the trends may still be of value.)

In total, more than 250 papers were examined in some degree of detail. After analyzing the collected material, we chose to use an inductive approach inspired by Boell et al. (2014), as well as a bottom-up approach to create our taxonomy (Baden-Fuller \& Morgan, 2010). As we listed and started to categorize all keywords on a whiteboard, we soon found interconnections and relations between them, and ended up creating a categorization. In e-commerce, we found, for example, Web 1.0, business-to-consumer (B2C), C2C, e-shops, emalls and e-auctions, while for social commerce we found Web 2.0, C2C, C2B, word-of-mouth, trust, branding, group purchase, user-generated content, platforms, and content creators. By using this basis in combination with business model theory, we decided to use the terms value creation, value capture and business model type (BM type), as subheadings when we characterized the content creator business models. As we started to look into the characterization of business

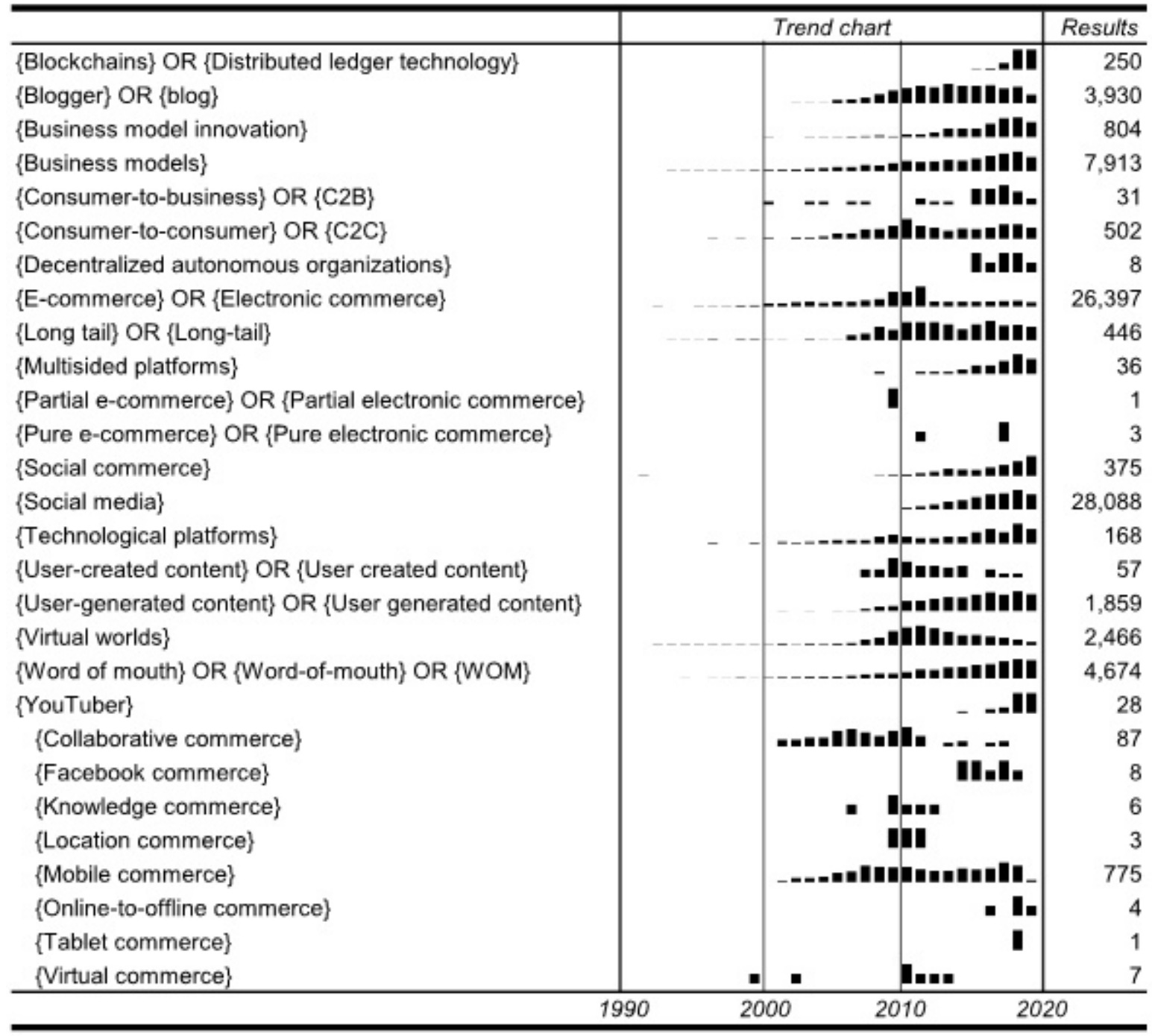

Table 2. Trend of published articles on Scopus 


\section{Towards a Taxonomy of E-commerce: Characterizing Content Creator-Based Business Models Martin D. Mileros, Nicolette Lakemond and Robert Forchheimer}

model types according to our first research question, we could see that the protection according to our second research question seemed to be dependent on whether the content had been created inside or outside of a platform. As we started to deal with the different combinations of where the value can be created and captured, we finally ended up with the structure represented in Table 3, showing eight types of content creator-based business models. We decided to use brackets [ ] to symbolize when the value creation and value capture occurred inside the boundaries of a platform. Surprisingly, when adding examples for the eight business model types we only succeeded in finding examples for seven of them.

Below, the results of the literature study are described in a detailed account of the findings related to the main concepts. Based on this, in the discussion section, we point to potential gaps and propose an agenda for future research that will contribute to an in-depth understanding of content creator-based business models.

\section{Results}

We first present the results from our literature review, and highlight the main concepts: electronic commerce, social commerce, platforms, and user-generated content. Second, we present the results of our business model characterization. And finally we present a summary of all results as a taxonomy of e-commerce (Appendix).

\section{Electronic Commerce}

The introduction of the World Wide Web in the early 1990s, denoted as Web 1.0 (Singh et al., 2008), gave rise to a new type of online commerce, referred to as ecommerce. Zwass (1996) defined e-commerce as sharing business information, maintaining business relationships, and conducting business transactions through telecommunications networks. Timmers (1998) defined e-commerce, according to the definition of the European Commission in 1997, as doing business electronically. He also characterized e-commerce as the electronic trading of physical goods and intangibles, such as information, through e-shops, e-malls (websites with multiple e-shops), or e-auctions. Choi et al. (1997) defined e-commerce according to the following three dimensions: agent (for example a supplier), channel (for example a website), and product or service, all three of which can be in the physical or virtual domain, and where at least one of them needs to be in the virtual domain in order to count as e-commerce. If a business is working solely within virtual dimensions, it is referred to as pure e-commerce, in other words, the agent, channel, and product or service are solely handled within the virtual domain. Wu et al. (2011) stated that the most common business relations within e-commerce are B2B, $\mathrm{B} 2 \mathrm{C}$, and $\mathrm{C} 2 \mathrm{C}$. Online auctions are based on C2C relations, for instance, where consumers can make transactions directly with each other. Group buying is considered a unique, innovative, and interesting online C2B business model type, which enables buyers to obtain volume discounts and helps sellers to sell a considerable number of items (Wang et al., 2016). Chen et al. (2008) referred to previous findings stating that $\mathrm{C} 2 \mathrm{C}$ business was emerging but C2B business seemed to be under-represented.

\section{Social Commerce}

Social commerce or social e-commerce is based on Web 2.0, a term popularized by Tim O'Reilly and Dale Dougherty in 2004 (Singh et al., 2008). Harrison and Barthel (2009) point out that Web 2.0 is not a new technology, but instead an introduction of several new tools on the Internet, such as asynchronous JavaScript and XML, together referred to as AJAX. They also add that these tools create and enable an architecture for participation and user interactions, shared knowledge and shared information among consumers, and also agree that Web 2.0 is about participating while Web 1.0 is about receiving information. This view is also supported by Busalim and Hussin (2016), who argue that ecommerce provides a classic one-way business relationship where information rarely is sent back to the seller or other customers, as compared to social commerce, which is seen as a multidimensional information flow between customers and sellers. Stephen and Toubia (2009) point out that social commerce can connect online shops to other online retailers through marketplaces.

Marketplaces usually comprise a large number of eshops, which increases the service of the customer demand according to the long-tail concept (Anderson, 2008). Kim (2013) sees social commerce as users participating in buying and selling products and services through digital platforms. The term social commerce was introduced by Yahoo in 2005 to describe a new collaborative shopping feature on its shopping platform that allowed consumers to create, share, and comment on product lists (Wang \& Zhang, 2012). Many consider social commerce as collective bargaining power for endusers, and argue that the Internet has shifted the bargaining power away from sellers to consumers (Kim, 2013). Banks and Humphreys (2008), Kane (2007) and Kim et al. (2008) see social commerce as utilizing Web 2.0 in e-commerce, particularly core Web 2.0 features, 


\section{Towards a Taxonomy of E-commerce: Characterizing Content Creator-Based Business Models Martin D. Mileros, Nicolette Lakemond and Robert Forchheimer}

such as user-generated content and content sharing. Huang and Benyoucef (2015) contribute the view that social commerce can be achieved in the following two ways: bringing e-commerce to social media or bringing social media to e-commerce websites. Social commerce can also be explained from many different perspectives, such as marketing, retailing, computer science, sociology, and psychology, making it hard to agree on a common definition (Huang \& Benyoucef, 2015). Busalim and Hussin (2016), as well as Yadav et al. (2013), support that view, arguing that there is a lack of clarity in the literature regarding the meaning and domain of social commerce.

Like for business models, Liang et al. (2011) state that there is no agreed definition of social commerce, but they identify two fundamental elements, namely social media and commercial activities. Social commerce is mainly seen by scholars as a subset of e-commerce (Hajli, 2014; Kim, 2013; Stephen \& Toubia, 2010). Huang and Benyoucef (2013) claim that social commerce is not fully understood, and Zhang and Benyoucef (2016) state that the literature in social commerce reveals multiple inconsistencies. Libai et al. (2010) claim that C2C has the potential to change consumers' preferences, actual purchase behaviour, or the way they further interact with others through the power of word-of-mouth. Before word-of-mouth, individuals spread news about a brand through offline $\mathrm{C} 2 \mathrm{C}$ interactions, in various environments face-to-face (in store, at home, in cars, at work), where $\mathrm{C} 2 \mathrm{C}$ in stores was likely to be the most powerful (Figallo \& Rhine, 2001; Libai et al., 2010). Hajli (2014) defines word-of-mouth as the occurrence when consumers share their experiences about a product or present their view to other consumers. According to Gefen (2000), word-of-mouth is important not only for branding, but also for gaining trust. Hennig-Thurau and Walsh (2003) found that consumers read online recommendations to save time in decision-making and to improve buying decisions.

\section{Platforms}

Platforms started to appear thanks to Web 2.0 technologies, which Rochet and Tirole (2003) described as two-sided markets. They discussed the challenge of getting the two sides (for instance, suppliers and customers or content creators and viewers) on board, which is referred to as the chicken-and-egg problem. Platforms can deal with more than two sides however. For example, Hagiu and Wright (2014) defined multisided platforms as organizations that get two or more sides on board and enable direct interactions between them. Garcia-Swartz and Garcia-Vicente (2015) characterized platforms as managing two or more distinct types of customers (users, application developers, handset manufacturers, network operators and advertisers). Korhonen et al. (2017) see platforms as multisided markets where value is created for all members of the network, and in which the purpose of a platform is to facilitate the exchange of products, which can be goods, greater accessibility, speed, efficiency, user experience, and convenience, and also enabling novel types of business models. Korhonen et al. mention that the definition of platforms has been inconsistent, although it has proliferated in management research. Gawer (2014) refers to technological platforms and central firms, such as Google, Apple, and Facebook. She also states that there are two fundamental views regarding platforms, namely the economic view as described by Rochet and Tirole (2003), and also an engineering view. Saarijärvi et al. (2018) note that despite the increasing amount of literature surrounding C2C e-commerce, the role of the platform has remained largely unexplored, and the literature still lacks insights on the distinct characterizations of different C2C ecommerce platforms, as well as how they influence consumers' perceptions of value and future behaviour.

Some platforms consist of virtual worlds, for which Kaplan and Haenlein (2010) characterized two types: virtual social worlds where users appear as avatars and interact as in real life, and virtual gaming worlds where users behave according to stricter rules. Value and transactions do not necessarily need to go through platforms, but with new technology such as peer-to-peer (P2P) communication and blockchains, can now be transferred directly between consumers (Swan, 2017; Tapscott, 2017). This type of value transfer can also make use of blockchain-based applications such as smart contracts and decentralized autonomous organizations (DAOs) (Mehar et al., 2019; Ryan, 2017), in which a whole organization is represented by rules encoded as a computer program.

\section{User-Generated Content}

Barnes (2002) characterizes content creators as users who create digital material (creative works), such as text, images, sounds, videos, and combinations of these, all of which are subject to copyright law (see also Kaplan and Haenlein, 2010). Dye (2006) states that content creators are consumers as well. In 2009, Van Dijck categorized these creators into the following three classes: entertainment, career, and family. Van Dijck also refers to the earliest content creators who were helping AOL in 1999 by monitoring their website for user content. A small number of these content creators, so-called remote staffers, got reimbursed for their contributions, which resulted in major discord among unpaid remote 


\section{Towards a Taxonomy of E-commerce: Characterizing Content Creator-Based Business Models Martin D. Mileros, Nicolette Lakemond and Robert Forchheimer}

staffers and ended with a lawsuit against AOL. Other contributions on the Internet were blogs, a shortened version of the term Web Log. Blogs began as Internet journals in the 1990s where people created links to interesting content, and some of them also generated income by promoting a product (Van Esch et al., 2018). More recently, YouTubers have become popular as for example video game commentary (Postigo, 2016). But there are also setbacks with this new phenomenon, when for instance YouTubers are abandoned or accused of misuse by their followers (Jerslev, 2016).

\section{Characterization of Content Creator-based Business Models}

From the literature study, we noticed that there seems to be a specific subset of commerce within social commerce, which consists of content creators who contribute their intellectual skills in order to make money (Angehrn et al., 2009; Postigo, 2016; Van Dijck, 2009). We decided to refer to this type of commerce as intellectual commerce, since the commerce of the content creators is based on intellectual creations. The first $\mathrm{C}$ in the business relationship $\mathrm{C} 2 \mathrm{C}$ and $\mathrm{C} 2 \mathrm{~B}$ within intellectual commerce here refers to business-oriented content creators (creators). In contrast, regarding the same relations within social commerce, $\mathrm{C}$ mainly refers to consumers without intentions of making money. Some content creators may have a legal entity or business, consist of several persons, or be considered professional amateurs.

As seen in Figure 1, we identified that the value of intellectual commerce by a content creator $\mathrm{C}$ can be created in two ways: outside a platform, as in Figure 1a, or inside a platform, as in Figure $1 \mathrm{~b}$. The value capture turns out to follow the same procedure, namely that value can be captured outside a platform from consumers $\mathrm{C}$ or businesses $\mathrm{B}$ or inside a platform by consumers $[\mathrm{C}]$ or the business (platform itself) [B]. The bidirectional arrows in Figure 1 symbolize the value creation (arrows pointing from the creator) and value capture direction (arrows pointing towards the creator). We would also stress that creations by the creator normally are covered by copyright law when created outside a platform. When created inside a platform, terms mainly apply which may overrule the copyright and limit any further commercialization such as exclusivity rights.

In total we end up with the following eight combinations of content creator-based business models (BM types), as listed in Table 3, and which also corresponds to our first research question of how content creator-based business models can be characterized. In response to our second research question, we can also observe how value is created, captured, and protected, as seen in Figure 1.

\section{Discussion}

Value in social commerce is mainly created by content creators and delivered by platforms instead of websites, as in traditional e-commerce. We agree with Hajli (2014), Kim (2013), and Zhang and Benyoucef (2016) in seeing social commerce as a subset of e-commerce. The C2C and C2B relationships are important in social commerce where consumers do not focus on making money. Instead, users are more or less working for free (Postigo, 2016), for instance, by disseminating trust and branding products through word-of-mouth (Halliday, 2016; Jones \& Leonard, 2008; Ng, 2013), or uploading images and videos on social media as user-generated content (Van Dijck, 2009).

In intellectual commerce, the content creators are business-oriented, as the $\mathrm{C}$ indicates that they all have a business model in mind, as stated by Chesbrough (2007). We have divided intellectual commerce by content creators creating value outside and inside a platform. When content creators create value outside a platform, it needs to be delivered by some external channels that are not considered in this study. Value created inside a
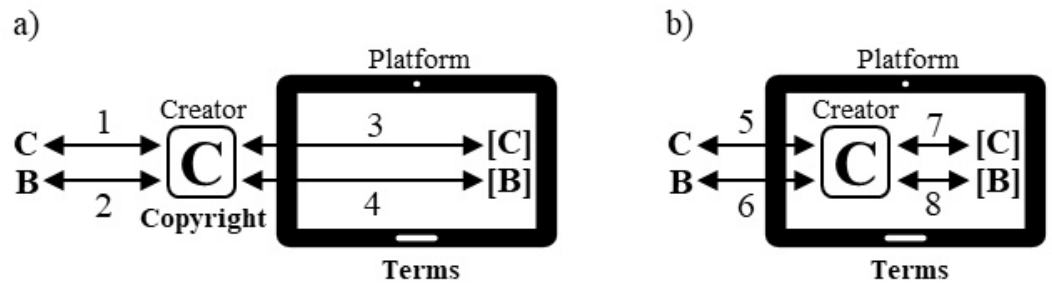

Figure 1. Eight business model types of value creation (arrows pointing out from the large C) and value capture (arrows pointing towards the large C) by business-oriented content creators where a) shows 4 types when value is created outside a platform, and b) shows 4 types when value is created inside a platform. 


\section{Towards a Taxonomy of E-commerce: Characterizing Content Creator-Based Business Models Martin D. Mileros, Nicolette Lakemond and Robert Forchheimer}

\begin{tabular}{ccccc}
\hline No. & Value creation & Value capture & Initial rights & BM Type \\
\hline & & & & \\
1 & Outside platform & Outside platform & Copyright & C2C \\
2 & Outside platform & Outside platform & Copyright & C2B \\
3 & Outside platform & [Inside platform] & Copyright & C2[C] \\
4 & Outside platform & [Inside platform] & Copyright & C2[B] \\
5 & [Inside platform] & Outside platform & Terms & {$[\mathrm{C}] 2 \mathrm{C}$} \\
6 & [Inside platform] & Outside platform & Terms & {$[\mathrm{C}] 2 \mathrm{~B}$} \\
7 & [Inside platform] & [Inside platform] & Terms & {$[\mathrm{C} 2 \mathrm{C}]$} \\
8 & [Inside platform] & [Inside platform] & Terms & {$[\mathrm{C} 2 \mathrm{~B}]$} \\
\hline
\end{tabular}

Table 3. Eight business model types for content creators within intellectual commerce. The brackets symbolize value limited by the boundaries (terms) of a platform.

platform may be delivered through the platform, and may also be commercialized within the platform. We would also like to clarify that creators can make use of two or more types of business at the same time, for example YouTubers who may be reimbursed by the platform for their content, and at the same time being reimbursed by businesses for promotion of products (Postigo, 2016; Van Dijck, 2009).

\section{Intellectual commerce}

Refers to commerce by content creators or more specifically as publicly accessible creative works made by non-professionals (such as UGC) with the intention of making money. The main difference between social commerce and our definition of intellectual commerce is that commerce in social commerce is carried out by businesses, even though creators are providing content. Intellectual commerce refers to business-oriented content creation as it both provides content and makes money. We would also like to clarify that in $\mathrm{C} 2 \mathrm{C}$ eauctions, consumers engage in commerce, but mainly involving physical products rather than original online intellectual contributions.

\section{Explanation of intellectual commerce and content creator-based business model types}

Below we describe our eight content creator business model types of intellectual commerce, and have also added some supportive and complementary references.

\section{1. $C 2 C$}

Some blockchain-based services for content creators enable them to sell or license their material directly to other consumers utilizing blockchain technology, taking care of reimbursements as well as managing property rights. Many of these services are still in an early development stage (McConaghy et al., 2017; Mehar et al., 2019; Nowiński \& Kozma, 2017; Ryan, 2017; Swan, 2017).

\section{2. $C 2 B$}

This relation may refer, for instance, to bloggers and YouTubers who communicate brands of external businesses in their content. This value stream can be accomplished even when a platform is used to commercialize the content. Some bloggers use platforms for their blogs, which may imply limitations (Korhonen et al., 2017; Postigo, 2016; Van Dijck, 2009).

\section{3. $C 2[C]$}

The relation refers to creations being developed outside a platform and uploaded to a platform. The creators are reimbursed by consumers within the platform. We have not found any examples of this business model type.

\section{4. $C 2[B]$}

This relation refers to creations which are being developed outside the platform and uploaded to a platform. The creators are reimbursed by the platform (rather than by consumers), for example, for providing video contributions to YouTube (Postigo, 2016).

\section{5. $[C] 2 C$}

The creation is developed within the boundaries of a platform such as a cloud service. The platform allows the creator to download the creation and also allows reimbursement outside of the platform. An example could be an author who writes a manuscript using a cloud service. Distribution to the consumers may be handled by blockchain technology or by means of thirdparty (intermediary) solutions (McConaghy et al., 2017; Mehar et al., 2019; Nowiński \& Kozma, 2017; Ryan, 2017; Swan, 2017). 


\section{Towards a Taxonomy of E-commerce: Characterizing Content Creator-Based Business Models Martin D. Mileros, Nicolette Lakemond and Robert Forchheimer}

\section{6. $[C] 2 B$}

This relation relates to content creators who develop their creative works within the boundaries of a platform, and who are allowed to download, control, and get reimbursed for their creative works outside of the platform. For instance, an author writing a manuscript in a cloud service such as Google Docs, downloads it and submits it to a publisher (Business). By using a platform, the creator may encounter limitations such as not being able to grant exclusivity to the publisher. Another example could be when taking photos with a mobile phone. Depending on which app (phone) or third-party app is used to take the photo, different rights and exclusivity issues may apply (Lippi et al., 2019; Steinfeld, 2016).

\section{7. $[C 2 C]$}

This type of model mainly refers to virtual worlds where content is created and traded among consumers within the platform, for example, avatars in virtual social worlds such as Second Life (Kaplan \& Haenlein, 2010).

\section{8. $[\mathrm{C2B}]$}

This last type refers to creators who, for example, develop apps for App Store or Google Play and get reimbursed by those platforms. Once the provided content is created it cannot be used or commercialized outside that specific platform or environment. A borderline case example is Amazon Mechanical Turk, where human intellect is used to solve different tasks, so-called Human Intelligence Tasks (HITs) (Peer et al., 2017).

As the platform provides the market channels, we have noticed that it is hard to find examples of the $\mathrm{C} 2 \mathrm{C}$, and $[\mathrm{C}] 2 \mathrm{C}$ relationship. For instance, the $\mathrm{C} 2 \mathrm{C}$ relationship has been around since the end of the1990s, and distributed by peer-to-peer software, such as KaZaA (Lambrick, 2009) and Napster (Newman, 2018; Smith, 2004), that led to piracy due to uncontrolled sharing and distribution without any structured possibilities for creators to receive reimbursement. Blockchain technology may again allow for P2P distribution to be carried out as a complement on or to platforms, this time within a semi-controlled manner, and with opportunities to properly reimburse creators. Many blockchain-based start-ups have already been launched (McConaghy et al., 2017; Mehar et al., 2019; Nowiński \& Kozma, 2017; Ryan, 2017; Swan, 2017).

As a comment we would like to point out that business relationships seem to have gained in importance since business models can be applied also to content creators and their $\mathrm{C} 2 \mathrm{~B}$ and $\mathrm{C} 2 \mathrm{C}$ relationships. A second comment is that distinguishing where and how value is created may become more important. For instance, if the value is created outside a platform, then it is automatically covered by copyright law according to national and international regulations. If the content instead is created inside a platform (or perhaps within an app), the terms of the platform may set the terms for how the content can be used or distributed inside or outside of that platform.

\section{Conclusions}

Our contribution is threefold. First, we have provided a taxonomy where we have explained and characterized 19 concepts within Web 1.0, Web 2.0, and e-commerce (Appendix).

Our second contribution, which corresponds to our first research question, is that we found eight business model types for business-oriented content creators that we have characterized (Figure 1), further explained and discussed. We have given examples for almost all business model types, except for $\mathrm{C} 2[\mathrm{C}]$, which refers to when consumers develop creative works outside a platform, but are reimbursed by consumers within a platform. This business model type seems to be unprecedented, about which we request any available input and suggestions.

Third, we also state that business-oriented content creators or professional amateurs have the intention of getting reimbursed for their efforts, in contrast with traditional content creators as well as the definition of user-generated content within social commerce. They must therefore pay attention to where they develop their creative works. If they develop them outside a platform, then the creative work is normally covered by copyright law as soon as it exists, but if a creative work is made within the boundaries of a platform, then the platform terms will apply and may overrule the copyright or in other ways limit the right to commercialize (for instance, exclusivity rights). This explanation corresponds to our second research question about created value. We introduced the term intellectual commerce to refer to business-oriented content creators making C2C and C2B businesses. This was placed in contrast to the same relations within social commerce, which mainly refer to e-auctions (C2C) or group-buying (C2B). The results imply that it is important for business-oriented content creators to understand the type of consumer and business relations in order to develop an appropriate business model.

As current research has been scarce and disparate we 


\section{Towards a Taxonomy of E-commerce: Characterizing Content Creator-Based Business Models Martin D. Mileros, Nicolette Lakemond and Robert Forchheimer}

hope that our more unified view of content creatorbased business models can give rise to a better understanding of the research field, thus also leading to more focus on the relevant phenomena. Furthermore, as we have identified different value streams, practitioners may acquire clearer and deeper insights into the prerequisites and conditions for e-commerce, as well as gain a better understanding of its current preconditions and limitations.

Finally, we would like to point out three areas for further research. First, a better understanding with respect to new types of content creator-based business and whether they can be aligned with our eight content creator business model types needs to be developed (for example, by in-depth empirical studies). Second, there seems to be a lack of understanding regarding the key characteristics of intellectual commerce, for instance, whether or not creators care about or are personally invested in business models, and what the main drivers are (money, fame, or perhaps fun) for their participation on platforms. Other questions may apply on how creators protect their values, what the potential setbacks might be, as well as how long they can keep on going. Third and last, we would like to point to policy issues, structures, and legal frameworks, for example, requirements on content creators, as well as the need for registered firms dealing with how taxes and other legal issues are handled.

\section{Acknowledgements}

An earlier version of this paper was presented at the International Society for Professional Innovation Management (ISPIM) conference in Florence, Italy, June 16-19, 2019. We would also like to acknowledge Charlotte Norrman and Magnus Klofsten at Linköping University for valuable feedback.

\section{Appendix. Taxonomy of e-commerce divided by Web 1.0 and Web 2.0 concepts}

\section{Descriptions of concepts and related references}

\section{Web 1.0 (Business centric)}

The World Wide Web (Web 1.0) was introduced in 1989 by Sir Timothy John Tim Berners-Lee. At that time the web was first utilized by individuals and their personal websites which were connected with hyperlinks. In the mid '90s, businesses started to get established on the web which gave birth to the business-centric era with increased focus towards business models.

Singh, et al., 2008; Timmers, 1998

\section{Business Models (BM)}

There is no generally accepted definition of business models, but one view is that it is a model of how to do business. A business model may be seen as a tool which helps the business to calculate revenues, costs for business actors and their roles, for example, customers, suppliers, and partners. The model may also reveal if the business may be able to sustain itself and how much profit can be expected.

Amit \& Zott, 2001; Baden-Fuller \& Morgan, 2010; Chesbrough, 2007; Foss \& Saebi, 2016; Teece, 2010; Timmers, 1998

\section{Business-to-Consumer (B2C)}

A traditional business relationship between a business B and a consumer (customer) C.

Pavlou, 2003

\section{Consumer-to-Consumer (C2C)}

Business relationship between two consumers which may utilize an e-auction (within e-commerce) to trade items directly between each other. The term is sometimes also referred to as customer-to-customer or individual-to-individual (I2I). C2C within intellectual commerce refers to a $\mathrm{C} 2 \mathrm{C}$ relation where a businessoriented content-creator is doing the commerce based on intellectual skills and creative works.

Antony, Lin \& Xu, 2006; Du et al., 2012; Jones \& Leonard, 2008; Leonard \& Jones, 2010; Libai et al., 2010; Saarijärvi et al., 2018

\section{Copyright}

Copyright is a national legal right which helps creators to protect the original expression of their creative work. 


\section{Towards a Taxonomy of E-commerce: Characterizing Content Creator-Based Business Models Martin D. Mileros, Nicolette Lakemond and Robert Forchheimer}

Copyright is complex as it comes with many exemptions (e.g. fair use) and many nation-specific conditions. It mainly consists of two rights, an economic right, that for instance allows creators to be reimbursed for their efforts within a limited time period (in some nations 50 or 70 years after the death of the creator), and a moral right, that allows creators to be recognized for their creative works. The economic right is exclusive but quite often transferred to other parties such as a publisher. The right of being recognized normally remains. When creating contributions within a platform in several cases, both the economic and moral rights may be overruled, as for example in Minecraft, where several creators can collaborate and build entire worlds. Copyright does not protect the idea itself but instead the original expression from an idea, referred to as creative works.

García \& Gil, 2008; Newman, 2013

\section{Electronic Commerce or e-commerce (EC)}

Electronic commerce or e-commerce may be seen as doing business electronically, for instance, throughout online services. The term commerce is related, for example, to buying, selling, and trading activities, and is mainly seen as a subset of e-business, also including other activities such as marketing and other business activities. Some specific terms related to e-commerce are the e-shop, which refers to business sales throughout a website; the e-mall, which refers to a website containing a collection of e-shops, for example, Amazon or Alibaba; and finally, the e-auction, which refers to an online auction where buyers can bid on different items, for example, eBay.

Choi et al., 1997; Timmers, 1998; Wang et al., 2016; Wu et al., 2011; Zott et al., 2011; Zwass, 1996

\section{Long Tail (Short Tail)}

The long tail refers to a large amount of niched lowvolume products. For example, a physical bookstore needs to select high-volume authors (referred to as head or short tail) due to physical space limitations, in contrast with space online which is not limited.

Anderson, 2008; Lyubareva et al., 2014; Swan, 2017; Zhang et al., 2012

\section{Pure (Full) and partial e-commerce}

Pure e-commerce refers to when an agent (merchant), product/service, and delivery channel all coincide within the digital domain (carried out online). Partial ecommerce refers to the fact that some of them (but not all three) are carried out in the physical domain. For example, when clothes are ordered online, but delivered by traditional mail, the agent belongs to the digital domain, while the product and delivery belong to the physical domain. If all three are carried out in the physical domain it becomes traditional commerce within the physical world.

Choi et al., 1997; Dey \& Nath, 2012; Yang et al., 2017; Yayla \& Hu, 2011

\section{Web 2.0 (Consumer centric)}

Web 2.0 (popularized by Tim O'Reilly and Dale Dougherty in 2004) is seen as an enhancement of Web 1.0 by utilizing new technologies, such as asynchronous JavaScript and Extensible Markup Language (XML), together referred to as AJAX. The tools made the web more dynamic, gave rise to platforms, and facilitated users' interactions. As the business-centric Web 1.0 was about providing information, the consumer-centric Web 2.0 is focused on participation. Concepts of Web 2.0 are, for instance, platforms, user-generated content, content creators, social commerce, and social media.

Hajli, 2013; Harrison \& Barthel, 2009; Singh et al., 2008

\section{Blockchains (DLT, DAO)}

Blockchains consist of network software protocols that manage transactions of value and ownership over the Internet in a decentralized manner, without the need of any third parties (intermediaries). The technology is mainly based on peer-to-peer (P2P) technology, cryptography, and an immutable ledger (file that keeps track of the transactions) by which a user may transfer values (for example, digital tokens and assets) to other parties on the same blockchain. There are two types of blockchains, public and private, where bitcoin represents a public blockchain (where the user's real identity is not known), in contrast to private blockchains, the latter which mainly are managed as business consortia or by governments and where user identities are known. Distributed ledger technology (DLT) is a more general form of the technology based on a ledger, consensus update, cryptographic signatures, and tamper-proof auditable history, without necessarily being updated by sequences of blocks such as a blockchain. Some blockchains may also encompass possibilities of handling decentralized autonomous organizations (DAOs), which may be seen as organizations represented by rules encoded as a computer program.

McConaghy et al., 2017; Mehar et al., 2019; Nowiński \& Kozma, 2017; Ryan, 2017; Swan, 2017; Tapscott, 2017

\section{Business Model Innovation}

Business model innovation mainly refers to when a 


\section{Towards a Taxonomy of E-commerce: Characterizing Content Creator-Based Business Models Martin D. Mileros, Nicolette Lakemond and Robert Forchheimer}

business changes one or multiple components in their business model, such as introducing a novel way to create or capture value (for example, licensing instead of selling products).

Amit \& Zott, 2012; Björkdahl \& Holmén, 2013; Frankenberger et al., 2013

\section{Consumer-to-Business (C2B)}

In social commerce the relation refers to group buying (a group of consumers who get together) in order to obtain volume discounts. In intellectual commerce the relation may refer to creators (for instance bloggers) making money by promoting business products.

Chen et al., 2008; Vanmeter et al., 2015; Wang et al., 2002; Yrjölä et al., 2017

\section{Platforms}

Platforms facilitate users to upload or develop content and can be seen as organizations which serve and create value for two or more distinct types of customers: application developers, manufacturers, advertisers, and consumers. An early stage problem that platforms must overcome is referred to as the chicken-and-egg problem. For example, YouTube needed to have many content creators to be able to attract viewers, but at the same time content creators require many viewers in order to incentivize their efforts into producing and sharing creative works. After accomplishing a critical mass, platforms may have the ability to utilize network effects (NE), which may trigger self-reinforcing feedback loops that can magnify incumbents' early advantages, and thus lead the platform to a winner-takes-all outcome. The purpose of a platform is to facilitate the exchange of products or information but also to provide greater accessibility, speed, efficiency, user experience, and convenience. Marketplaces usually comprise of eauctions (for example, C2C trading), but also e-malls that utilize the long-tail concept.

Dufva et al., 2017; Garcia-Swartz \& Garcia-Vicente, 2015; Hagiu \& Wright, 2014; Holland \& Gutiérrez-Leefmans, 2018; Korhonen et al., 2017; Rochet \& Tirole, 2003; Stephen \& Toubia, 2009

\section{Social Commerce or s-commerce (SC)}

Social commerce means commerce through social interactions by consumers. Social commerce is mainly seen as a subset of e-commerce or as utilizing Web 2.0 features in e-commerce. Traditional e-commerce is mainly seen as a one-directional business relationship where information rarely is sent back to the business compared to social commerce, which constitutes a multidimensional flow between businesses and consumers. The term social commerce was introduced in 2005 when Yahoo allowed consumers to create, share, and comment on product lists of a collaborative shopping feature on their platform.

Banks \& Humphreys, 2008; Busalim \& Hussin, 2016; Hajli, 2014; Huang \& Benyoucef, 2013; Kane, 2007; Kim et al., 2008; Liang et al., 2011; Stephen \& Toubia, 2010; Yadav et al., 2013; Zhang et al., 2012

\section{Social Media (SM)}

Social media mainly consist of online services which facilitate communication channels of information between different types of users in a multidirectional way. The information can consist of entertainment, news, education, discourse, or user-generated content.

Halliday, 2016; Kaplan \& Haenlein, 2010; Liang et al., 2011; Saarijärvi et al., 2018; Vanmeter et al., 2015

\section{Terms}

The terms of service, which mainly are provided by a business, specify the rights and obligations which apply to the users of the service. Terms may also include a privacy policy which states how personal data will be protected and handled. There are different connotations for user terms, for instance, terms and conditions, terms of service, service agreements, or statements.

Lippi et al., 2019; Steinfeld, 2016

\section{User-Generated Content (UGC, UCC)}

User-generated content may be seen as publicly accessible creative works made by non-professionals. More specifically, the three parts may be addressed as: 1 ) it needs to be publicly accessible; 2 ) it needs to include some creative effort; and 3) it needs to be created outside of professional routines. The term became popular in 2004 and according to our trend analysis seems to have been referred to as user-created content (UCC) (Table 2). It may also be mentioned that in the early 1990s, its early users created all of its content. Some common terms of content creators applied on the Internet are, hobbyists, amateurs, unpaid labourers, and volunteers. The term perhaps should have a broader definition nowadays and not only cover creative contributions, as the boundary between amateurs and professionals has also become more dynamic. Normally, consumers or users contribute online by submitting text, image, sound, video, and combinations of them (multimedia). Such creative works are subject to copyright.

Angehrn et al., 2009; Banks \& Humphreys, 2008; Barnes, 


\section{Towards a Taxonomy of E-commerce: Characterizing Content Creator-Based Business Models Martin D. Mileros, Nicolette Lakemond and Robert Forchheimer}

2002; Dye, 2006; Figallo \& Rhine, 2001; Goh et al., 2013; Hajli \& Sims, 2015; Harrison \& Barthel, 2009; Kane, 2007; Kaplan \& Haenlein, 2010; Lai \& Turban, 2008; Postigo, 2016; Scarle et al., 2012; Van Dijck, 2009; Van Esch et al., 2018

\section{Virtual Worlds}

Virtual worlds are mainly characterized as virtual social worlds where users appear as avatars and interact as in real life, such as in Second Life, or as virtual gaming worlds where users behave according to stricter rules.

Kaplan \& Haenlein, 2010

\section{Word-of-Mouth (WOM)}

Word-of-mouth mainly refers to the interconnections between consumers that may be used to strengthen a brand or trust in an online product or service. It mainly solves the problem of not having a salesperson whom you can ask and gain trust from as in physical stores. Reviews by consumers are also seen as word-of-mouth and can improve buying decisions, as well as saving time for other consumers. Word-of-mouth is seen as powerful and can easily change consumer preferences and purchase behaviour.

Figallo \& Rhine, 2001; Gefen, 2000; Hajli, 2014; HennigThurau \& Walsh, 2003; Libai et al., 2010; Stephen \& Toubia, 2010

\section{References}

Amit, R., Zott, C. 2001. Value Creation in E-Business. Strategic Management Journal, 22: 493-520.

Amit, R., Zott, C. 2012. Creating Value Through Business Model Innovation. MIT Sloan Management Review, 53310.

Anderson, C. 2008. The Long Tail: How Endless Choice Is Creating Unlimited Demand. Random House.

Angehrn, A.A., Luccini, A.M., Maxwell, K. 2009. InnoTube: A Video-Based Connection Tool Supporting Collaborative Innovation. Interactive Learning Environments, 17: 205-220.

Antony, S., Lin, Z., Xu, B. 2006. Determinants of Escrow Service Adoption in Consumer-to-Consumer Online Auction Market: An Experimental Study. Decision Support Systems, 42: 1889-1900.

Baden-Fuller, C., Morgan, M.S. 2010. Business Models as Models. Long Range Planning, 43: 156-171.

Banks, J., Humphreys, S. 2008. The Labour of User CoCreators Emergent Social Network Markets? Convergence, 14: 401-418.

Barnes, S.J. 2002. The Mobile Commerce Value Chain: Analysis and Future Developments. International Journal of Information Management, 22: 91-108.

Björkdahl, J., Holmén, M. 2013. Editorial: Business Model Innovation - the Challenges Ahead. International Journal of Product Development, 18: 213-225.

Boell, S.K., Cecez-Kecmanovic, D. 2014. A Hermeneutic Approach for Conducting Literature Reviews and Literature Searches. Communications of the Association for Information Systems, 34: 257-286.

Busalim, A.H., Hussin, A.R.C. 2016. Understanding Social Commerce: A Systematic Literature Review and Directions for Further Research. International Journal of Information Management, 36: 1075-1088.

Chen, D., Jeng, B., Lee, W., Chuang, C. 2008. An AgentBased Model for Consumer-to-Business Electronic Commerce. Expert Systems with Applications, 34: 469481.

Chesbrough, H. 2007. Business Model Innovation: It's Not Just about Technology Anymore. Strategy and Leadership, 35: 12-17.

Chesbrough, H., Rosenbloom, R.S. 2002. The Role of the Business Model in Capturing Value from Innovation: Evidence from Xerox Corporation's Technology Spinoff Companies. Industrial and Corporate Change, 11: 529-555.

Choi, S., Whinston, A., Stahl, D. 1997. Economics of Electronic Commerce. Macmillan Computer Publishing.

Cucculelli, M., Bettinelli, C. 2015. Business Models, Intangibles and Firm Performance: Evidence on Corporate Entrepreneurship from Italian Manufacturing SMEs. Small Business Economics, 45: 329-350.

Dey, D., Nath, A. 2012. A Comprehensive Study on E- 


\section{Towards a Taxonomy of E-commerce: Characterizing Content Creator-Based Business Models Martin D. Mileros, Nicolette Lakemond and Robert Forchheimer}

Commerce Models: Merits, Demerits and Future Scope. International Journal of Advanced Computer Research, 2: 163-168.

Du, H.S., Yu, H., Fang, Y., Wang, S. 2012. Empirical Investigation of EachNet: The EBay Model of C2C Online Auction in China. IEEE Transactions on Engineering Management, 59: 160-175.

Dufva, M., Koivisto, R., Ilmola-Sheppard, L., Junno, S. 2017. Anticipating Alternative Futures for the Platform Economy. Technology Innovation Management Review, 7: 6-16.

Dye, J. 2006. Meet Generation C: Creatively Connecting Through Content. EContent-Digital Content Strategies and Resources, 30: 38-43.

Figallo, C., Rhine, N. 2001. Tapping the Grape. EContent, 24: 38-39.

Foss, N.J., Saebi, T. 2016. Fifteen Years of Research on Business Model Innovation: How Far Have We Come, and Where Should We Go? Journal of Management, 43: 200-227.

Frankenberger, K., Weiblen, T., Csik, M., Gassmann, O. 2013. The 4I-Framework of Business Model Innovation: A Structured View on Process Phases and Challenges. International Journal of Product Development, 18: 249-273.

Garcia-Swartz, D.D., Garcia-Vicente, F. 2015. Network Effects on the IPhone Platform: An Empirical Examination. Telecommunications Policy, 39: 877895.

García, R., Gil, R. 2008. A Web Ontology for Copyright Contract Management. International Journal of Electronic Commerce, 12: 99-114.

Gassmann, O., Frankenberger, K., Csik, M. 2013. The St. Gallen Business Model Navigator.

Gawer, A. 2014. Bridging Differing Perspectives on Technological Platforms: Toward an Integrative Framework. Research Policy, 43: 1239-1249.

Gefen, D. 2000. E-Commerce: The Role of Familiarity and Trust. Omega, 28: 725-737.

Goh, K.-Y., Heng, C.-S., Lin, Z. 2013. Social Media Brand Community and Consumer Behavior: Quantifying the Relative Impact of User- and Marketer- Generated Content. Information Systems Research, 24: 88-107.

Hagiu, A., Wright, J. 2014. Marketplace or Reseller? Management Science, 61: 184-203.

Hajli, M. 2013. A Research Framework for Social Commerce Adoption. Information Management \& Computer Security, 21: 144-154.

Hajli, M.N. 2014. The Role of Social Support on Relationship Quality and Social Commerce. Technological Forecasting \& Social Change, 87: 17-27.

Hajli, N., Sims, J. 2015. Social Commerce: The Transfer of Power from Sellers to Buyers. Technological Forecasting \& Social Change, 94: 350-358.

Halliday, S.V. 2016. User-Generated Content about Brands: Understanding Its Creators and Consumers. Journal of Business Research, 69: 137-144.
Harrison, T.M., Barthel, B. 2009. Wielding New Media in Web 2.0: Exploring the History of Engagement with the Collaborative Construction of Media Products. New Media \& Society, 11: 155-178.

Hennig-Thurau, T., Walsh, G. 2003. Electronic Word-ofMouth: Motives for and Consequences of Reading Customer Articulations on the Internet. International Journal of Electronic Commerce, 8: 51-74.

Holland, C.P., Gutiérrez-Leefmans, M. 2018. A Taxonomy of SME E-Commerce Platforms Derived from a Market-Level Analysis. International Journal of Electronic Commerce, 22: 161-201.

Huang, Z., Benyoucef, M. 2013. From E-Commerce to Social Commerce: A Close Look at Design Features. Electronic Commerce Research and Applications, 12: 246-259.

Huang, Z., Benyoucef, M. 2015. User Preferences of Social Features on Social Commerce Websites: An Empirical Study. Technological Forecasting \& Social Change, 95: 57-72.

Jensen, A.B. 2014. Do We Need One Business Model Definition? Journal of Business Models, 1: 61-84.

Jerslev, A. 2016. In the Time of the Microcelebrity: Celebrification and the YouTuber Zoella. International Journal of Communication, 10: 5233-5251.

Jones, K., Leonard, L.N.K. 2008. Trust in Consumer-toConsumer Electronic Commerce. Information \& Management, 45: 88-95.

Kane, S.K. 2007. Everyday Inclusive Web Design: An Activity Perspective. Information Research, 12.

Kaplan, A.M., Haenlein, M. 2010. Users of the World, Unite! The Challenges and Opportunities of Social Media. Business Horizons, 53: 59-68.

Kim, D. 2013. Electronic Commerce Research and Applications Under What Conditions Will Social Commerce Business Models Survive? Electronic Commerce Research and Applications, 12: 69-77.

Kim, D.J., Ferrin, D.L., Rao, H.R. 2008. A Trust-Based Consumer Decision-Making Model in Electronic Commerce: The Role of Trust, Perceived Risk, and Their Antecedents. Decision Support Systems, 44: 544-564.

Korhonen, H., Still, K., Seppänen, M., Kumpulainen, M., Suominen, A., Valkokari, K. 2017. The Core Interaction of Platforms: How Startups Connect Users and Producers. Technology Innovation Management Review, 7: 17-29.

Kotarba, M. 2018. Digital Transformation of Business Models. Foundations of Management, 10: 123-142.

Lai, L.S.L., Turban, E. 2008. Groups Formation and Operations in the Web 2.0 Environment and Social Networks. Group Decision and Negotiation, 17: 387402.

Lambrick, J. 2009. Piracy, File Sharing...and Legal Fig Leaves. Journal of International Commercial Law and Technology, 4: 185-195.

Leonard, L.N.K., Jones, K. 2010. Consumer-to-Consumer 


\section{Towards a Taxonomy of E-commerce: Characterizing Content Creator-Based Business Models Martin D. Mileros, Nicolette Lakemond and Robert Forchheimer}

e-Commerce Research in Information Systems Journals. Journal of Internet Commerce, 9: 186-207.

Liang, T., Ho, Y., Li, Y., Turban, E. 2011. What Drives Social Commerce: The Role of Social Support and Relationship Quality. International Journal of Electronic Commerce, 16: 69-90.

Libai, B., Bolton, R., Bügel, M.S., Ruyter, K. De, Götz, O., Risselada, H., Stephen, A.T., Stephen, A.T. 2010. Customer-to-Customer Interactions: Broadening the Scope of Word of Mouth Research. Journal of Service Research, 13: 267-282.

Lippi, M., Pałka, P., Contissa, G., Lagioia, F., Micklitz, H.W., Sartor, G., Torroni, P. 2019. Claudette: An Automated Detector of Potentially Unfair Clauses in Online Terms of Service. Artificial Intelligence and Law, 27: 117-139.

Lyubareva, I., Benghozi, P.-J., Fidele, T. 2014. Online Business Models in Creative Industries: Diversity and Structure. International Studies of Management \& Organization, 44: 43-62.

McConaghy, M., McMullen, G., Parry, G., McConaghy, T., Holtzman, D. 2017. Visibility and Digital Art: Blockchain as an Ownership Layer on the Internet. Strategic Change, 26: 461-470.

Mehar, M., Shier, C., Giambattista, A., Gong, E., Fletcher, G., Sanayhie, R., Kim, H., Laskowski, M. 2019. Understanding a Revolutionary and Flawed Grand Experiment in Blockchain: The DAO Attack. Journal of Cases on Information Technology, 21: 19-32.

Newman, J.M. 2013. Copyright Freeconomics. Vanderbilt Law Review, 66: 1409-1470.

Newman, J.M. 2018. The Myth of Free. George Washington Law Review, 86: 513-586.

$\mathrm{Ng}$, C.S. 2013. Intention to Purchase on Social Commerce Websites across Cultures: A CrossRegional Study. Information \& Management, 50: 609620.

Nowiński, W., Kozma, M. 2017. How Can Blockchain Technology Disrupt the Existing Business Models? Entrepreneurial Business and Economics Review, 5: 173-188.

Osterwalder, A., Pigneur, Y. 2010. Business Model Generation: A Handbook for Visionaries, Game Changers, and Challengers. John Wiley \& Sons.

Pavlou, P.A. 2003. Consumer Acceptance of Electronic Commerce: Integrating Trust and Risk with the Technology Acceptance Model. International Journal of Electronic Commerce, 7: 101-134.

Peer, E., Brandimarte, L., Samat, S., Acquisti, A. 2017. Beyond the Turk: Alternative Platforms for Crowdsourcing Behavioral Research. Journal of Experimental Social Psychology, 70: 153-163.

Postigo, H. 2016. The Socio-Technical Architecture of Digital Labor: Converting Play into YouTube Money. New Media \& Society, 18: 332-349.

Rochet, J.C., Tirole, J. 2003. Platform Competition in Two-Sided Markets. Journal of the European Economic Association, 1: 990-1029.
Ryan, P. 2017. Smart Contract Relations in E-Commerce: Legal Implications of Exchanges Conducted on the Blockchain. Technology Innovation Management Review, 7: 14-21.

Saarijärvi, H., Joensuu, J., Rintamaki, T., Yrjölä, M. 2018. One Person's Trash Is Another Person's Treasure: Profiling Consumer-to-Consumer e-commerce in Facebook. International Journal of Retail and Distribution Management, 46: 1092-1107.

Scarle, S., Arnab, S., Dunwell, I., Petridis, P., Protopsaltis, A., Freitas, S. De 2012. E-Commerce Transactions in a Virtual Environment: Virtual Transactions. Electronic Commerce Research, 12: 379-407.

Singh, T., Veron-Jackson, L., Cullinane, J. 2008. Blogging: A New Play in Your Marketing Game Plan. Business Horizons, 51: 281-292.

Smith, A.D. 2004. Potential for Growth and Security in Internet File- Sharing: The VPN Concept of Gnutella. Journal of Internet Commerce, 3: 1-19.

Steinfeld, N. 2016. 'I Agree to the Terms and Conditions': (How) Do Users Read Privacy Policies Online? An EyeTracking Experiment. Computers in Human Behavior, 55: 992-1000.

Stephen, A.T., Toubia, O. 2009. Explaining the PowerLaw Degree Distribution in a Social Commerce Network. Social Networks, 31: 262-270.

Stephen, A.T., Toubia, O. 2010. Deriving Value from Social Commerce Networks. Journal of Marketing Research, 47: 215-228.

Swan, M. 2017. Anticipating the Economic Benefits of Blockchain. Technology Innovation Management Review, 7: 6-13.

Tapscott, D. 2017. How Blockchain Will Change Organizations. MIT Sloan Management Review, 58: 10-13.

Taran, Y., Boer, H., Lindgren, P. 2015. A Business Model Innovation Typology. Decision Sciences, 46: 301-331.

Teece, D.J. 2010. Business Models, Business Strategy and Innovation. Long Range Planning, 43: 172-194.

Timmers, P. 1998. Business Models for Electronic Markets. Electronic Markets, 8: 3-8.

Van Dijck, J. 2009. Users like You? Theorizing Agency in User-Generated Content. Media, Culture \& Society, 31: 41-58.

Van Esch, P., Arli, D., Castner, J., Talukdar, N., Northey, G. 2018. Consumer Attitudes towards Bloggers and Paid Blog Advertisements: What's New? Marketing Intelligence and Planning, 36: 778-793.

Vanmeter, R.A., Grisaffe, D.B., Chonko, L.B. 2015. Of "Likes" and "Pins": The Effects of Consumers' Attachment to Social Media. Journal of Interactive Marketing, 32: 70-88.

Wang, C., Zhang, P. 2012. The Evolution of Social Commerce: The People, Management, Technology, and Information Dimensions. Communications of the Association for Information Systems, 31: 105-127.

Wang, K., Wang, E.T.G., Tai, C.-F. 2002. A Study of Online 


\section{Towards a Taxonomy of E-commerce: Characterizing Content Creator-Based Business Models Martin D. Mileros, Nicolette Lakemond and Robert Forchheimer}

Auction Sites in Taiwan: Product, Auction Rule, and Trading Type. International Journal of Information Management, 22: 127-142.

Wang, W., Wang, Y., Liu, E.-R. 2016. The Stickiness Intention of Group-Buying Websites: The Integration of the Commitment -Trust Theory and e-Commerce Success Model. Information \& Management, 53: 625642.

Weill, P., Malone, T.W., Apel, T.G. 2011. The Business Models Investors Prefer. MIT Sloan Management Review, 52: 17-19.

Wu, F., Li, H., Kuo, Y. 2011. Reputation Evaluation for Choosing a Trustworthy Counterparty in C2C ECommerce. Electronic Commerce Research and Applications, 10: 428-436.

Yadav, M.S., Valck, K. De, Hennig-Thurau, T., Hoffman, D.L., Spann, M. (2013) Social Commerce: A Contingency Framework for Assessing Marketing Potential. Journal of Interactive Marketing, 27: 311323.

Yang, Z., Shi, Y., Yan, H. 2017. Analysis on Pure ECommerce Congestion Effect, Productivity Effect and Profitability in China. Socio-Economic Planning Sciences, 57: 35-49.

Yayla, A.A., Hu, Q. 2011. The Impact of Information Security Events on the Stock Value of Firms: The Effect of Contingency Factors. Journal of Information Technology, 26: 60-77.

Yrjölä, M., Rintamäki, T., Saarijärvi, H., Joensuu, J. 2017. Consumer-to-Consumer e-commerce: Outcomes and Implications. International Review of Retail, Distribution and Consumer Research, 27: 300-315.

Zhang, K.Z.K., Benyoucef, M. 2016. Consumer Behavior in Social Commerce: A Literature Review. Decision Support Systems, 86: 95-108.

Zhang, X., Williams, A., Polychronakis, Y.E. 2012. A Comparison of E-Business Models from a Value Chain Perspective. EuroMed Journal of Business, 7: 83-101.

Zott, C., Amit, R. 2010. Business Model Design: An Activity System Perspective. Long Range Planning, 43: $216-226$.

Zott, C., Amit, R.H., Massa, L. 2011. The Business Model: Recent Developments and Future Research. Journal of Management, 37: 1019-1042.

Zwass, V. 1996. Electronic Commerce: Structures and Issues. International Journal of Electronic Commerce, $1: 3-23$.

Citation: Mileros, M.D., Nicolette Lakemond, N., \& Forchheimer, R. 2019. Towards a Taxonomy of E-Commerce: Characterizing Content Creator-Based Business Models. Technology Innovation Management Review, 9(10): 62-77.

http://doi.org/10.22215/timreview/1275

(cc) BY

Keywords: Content creator-based business models, e-commerce social commerce, consumer-to-business, multisided platforms, user-generated content, content creators, intellectual commerce, personal data, human-centered data economy

\section{About the Authors}

Martin D. Mileros is a third year industrial $\mathrm{PhD}$ student at Research Institutes of Sweden (RISE) and Linköping University in Linköping, Sweden. The research mainly concerns value of personal data within a human-centered data economy. Martin holds a MSc degree in Applied Physics and Electrical Engineering, a MSc degree in Computer Science and a Bachelor degree in Business Administration.

Nicolette Lakemond is Professor in Industrial Management at Linköping University, Sweden. She holds a PhD from Linköping University. Her research focuses on innovation and management challenges related to increasingly complex intelligent products and systems. This includes the organization of innovation, collaboration and knowledge integration, innovation in ecosystems, technology platforms and applications and innovation as recombination in new types of systems architectures. The research conducted is focused on unravelling future management challenges by research approaches that build on the tight connection between technology and management. She has previously performed research on innovation in complex and interorganizational settings, including buyer-supplier collaboration and customers' role in the knowledge supply chain of innovation, inter-firm collaboration in digitalization projects, and knowledge integration in open innovation. Her research has been published in among others Industrial Marketing Management, Industrial and Corporate Change, Technovation, R\&D Management, Creativity and Innovation Management, Journal of Purchasing and Supply Management, and Research Technology Management.

Robert Forchheimer is Professor Emeritus at Linköping University, Sweden. He graduated with a MSc degree in Electrical Engineering from the Royal Institute of Technology, Stockholm in 1972 and received his doctoral degree from Linköping University in 1979. His research areas have included telecommunication and signal processing. Today, his interests cover various aspects of the use of digital services with respect to safety and integrity. 